\title{
Paris university blasted over Israel motion
}

Declan Butler, Paris

The governing board of France's largest research university is facing a hail of protest from researchers both at home and abroad over its demand that the European Union (EU) sever its most important formal scientific link with Israel.

The outcry is a response to a motion passed by the board of the University of Pierre and Marie Curie - also known as the University of Paris 6 - calling for Israel's participation in the EU Framework Programme for research to be suspended. Around 2,500 protesters demonstrated at the university's Jussieu campus on 6 January, and an Internet petition against the move has attracted some 24,000 supporters.

The university's 60 -strong board passed a motion on 16 December saying that Israel should be excluded from the programme until Palestinian universities, which are in dire straits because of the Israeli occupation (see Nature 417, 209-210; 2002), are able to operate normally.

The motion, which was backed by trade unions and passed by 22 votes to 4 , stopped short of its initial demand that the university itself also suspend research collaboration with Israel. It also called on the university and Israeli researchers to act to alleviate the plight of Palestinian researchers.

Among those backing the Internet petition are nine Nobel prizewinners - among them David Baltimore, Claude Cohen-Tannoudji,

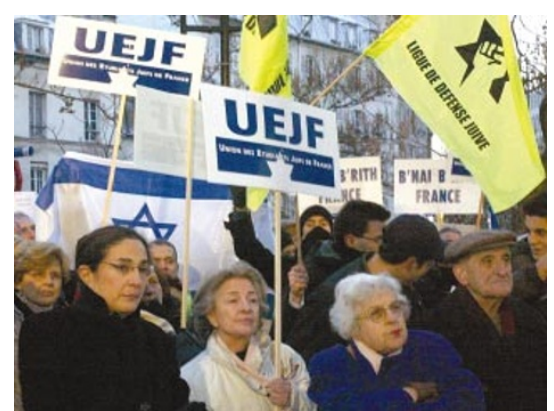

Out in the cold: protestors condemn a proposal to exclude Israel from research collaborations.

Elie Weisel and François Jacob. Cohen-Tannoudji, an honorary professor at the university, wrote in the French newspaper Le Monde of his "shame" at the motion's contents.

Critics of the motion include the national council of university vice-chancellors and Luc Ferry, the education minister. They say that the idea of punishing Israel's universities runs counter to the values of scientific collaboration, and that research is one of the few areas in which Jews and Arabs can still interact.

The petition's instigator, Bernard Maro, director of the developmental biology laboratory at the Paris university, wants the board to revoke the motion at its next meeting on 27 January. Otherwise, he says that he will leave the university and take his lab and its 120 staff elsewhere.

Maro is not alone: last week he led a delega- tion of scientists that presented Gilbert Bereziat, the vice-chancellor of the university, with a letter signed by 91 of its leading scientists, calling on the university to "denounce without ambiguity the motion, and apologize to our Israeli colleagues".

Bereziat, a biologist, says that the policy of the university — which has strong links with Israeli scientists — has not changed as a result of the motion, and that he would never cut off contacts with Israeli scientists.

The board itself remains deeply divided on the issue. Michèle Glass-Maujean, a physicist and board member who was abroad during the December meeting, says that the decision is beyond the board's remit. "I was elected to help run a university, not to take political positions - particularly on a situation as delicate as this," she says, adding: "The board would have done better to have done nothing." Supporters of the motion complain of hate mail calling them "fascists".

The vice-chancellor of the University of Paris 7, also on the Jussieu campus, intervened last week to block discussion of a similar motion by its board. Instead, the board passed one that lauds collaboration as fundamental to the international scientific community and a weapon against "extremism".

Meanwhile, 17 vice-chancellors of universities in the Paris area took this idea a step further, by calling on the EU to extend its agreement with Israel to explicitly include Palestinian universities.

\section{Pesticide firms ask to use human data to assess safety}

Tony Reichhardt, Washington

A lawsuit due to reach court in March could settle a contentious stand-off between pesticide manufacturers and the US Environmental Protection Agency (EPA) over whether human test data can be used to help set legal limits for pesticides released into the environment.

A group of pesticide suppliers and CropLife America, which lobbies for the pesticide industry, are suing the EPA in the District of Columbia Circuit of the US Court of Appeals, after the agency issued a ban on accepting human test data.

The outcome could affect sales of some of the mostly widely used pesticides on the market, including malathion, a crop insecticide, and dichlorvos, which is commonly found in domestic pest strips and flea collars.

Although such chemicals have been used for decades, a 1996 law tightened regulations governing their presence as residue in food (see Nature 396, 207; 1998). Because their toxic effect on humans is often unknown, the EPA takes the lowest toxic dose based on animal studies and divides by 100 to set limits for humans.

Pesticide manufacturers say that the uncertainty factor is too conservative in many cases, and that using data from tests on humans would allow the limits to be raised for some pesticides. With this in mind, they have submitted human toxicity data for at least 15 chemicals since the 1996 law came into effect.

But a 1998 report by the Environmental Working Group, a Washington-based lobby group that wants tighter controls on pesticide use, exposed details of human tests in Scotland (see Nature 394, 515; 1998), and raised ethical concerns about the practice. The EPA subsequently banned the consideration of human data in setting pesticide regulations, a decision it reaffirmed in December 2001, when it asked

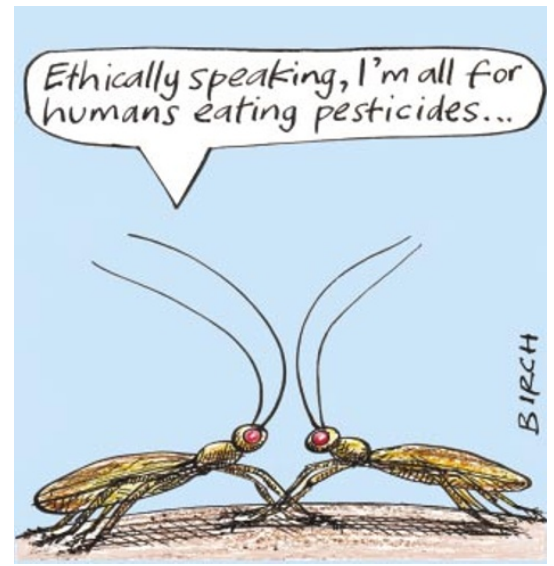

the National Academy of Sciences to look into the matter.

The academy panel charged with doing this, co-chaired by James Childress, a University of Virginia bioethicist, and Michael Taylor, a food-safety expert with 


\section{Ethics panel attacks environment book}

\section{Alison Abbott, Munich}

The author of the The Skeptical Environmentalist, a widely read book arguing that the global environment is basically in good shape, misused scientific data to support his arguments, the Danish Committees on Scientific Dishonesty has ruled.

The book was written by political scientist Bjørn Lomborg, who now heads Denmark's Institute for Environmental Assessment (IEA). In an unusual judgement issued on 6 January, the committees said that the book was, "objectively speaking, deemed to fall within the concept of scientific dishonesty". The report adds, however, that the book cannot be regarded as scientifically dishonest, because there is no evidence that Lomborg was grossly negligent or intended to deceive. It concludes instead that the book's publication "is deemed clearly contrary to the standards of good scientific practice".

The verdict was welcomed by researchers who have accused Lomborg of selective use of data and of falsely presenting his work as a formal scientific analysis. But others said they were astonished that a scientific ethics panel would pass judgement on a polemic - even one published by Cambridge University Press with thousands of references and footnotes.

Anthony Trewavas, a plant biologist at the University of Edinburgh, says that, although he doesn't always agree with Lomborg, the move "comes down almost to censorship", and that the committees should

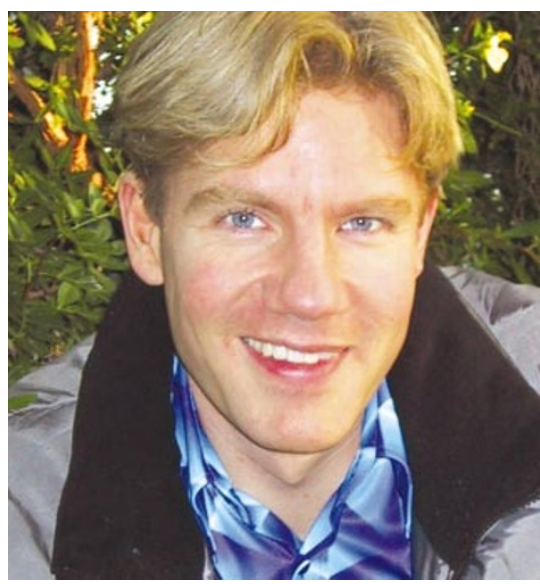

Bjørn Lomborg contends that an ethics committee was the wrong forum to judge his book.

never have agreed to consider the case in terms of scientific dishonesty: "Everyone has a right to express their opinion," he adds.

"There was not even unanimity within the committees or the working group set up to study the case as to whether it was in our sphere," Hans Henrik Brydensholt, the committees' chairman, told Nature. "But several issues convinced us that we could not choose simply not to comment."

For example, Lomborg identifies himself in the book as a scientist, and the University of Aarhus, where he is an assistant professor of statistics in the political-science depart-
Resources for the Future, held its first public meeting in Washington on 8 January, and plans to report its findings in December.

Industry representatives claimed at the meeting that the EPA's ban on human data violates its legal obligation to consider all relevant data in making pesticide decisions. California and the European Union each consider human test data in setting pesticide standards, they said.

A study funded by CropLife America that was presented at the meeting found that all 15 of the oral human tests submitted as evidence to the EPA since 1996 complied with accepted standards regarding informed consent, institutional review and other ethical practices.

Steven Lamm, an occupational-health consultant in Washington, said that "excluding ethically performed human studies is unethical".

But Jennifer Sass, a toxicologist at the Natural Resources Defense Council, an environmental lobby group, said at the meeting that her review of several human pesticide studies revealed flaws such as inadequate sample size or focusing on a single end-point in determining toxicity while ignoring other adverse health effects.

In theory, the EPA should be able to reject flawed studies, but it lacks the expertise to evaluate large numbers of human clinical studies, says Lynn Goldman, an environmental-health scientist at the Johns Hopkins Bloomberg School of Public Health and former head of the EPA's pesticides office.

Richard Wiles, vice-president for research at the Environmental Working Group, says that the EPA is under "enormous pressure from industry" to lift the ban on human tests. He adds that even if such studies are flawed, pesticide manufacturers will use them to try to influence debate about what constitutes a "safe" level of exposure to common pesticides. ment, listed it as a research monograph in its 2001 yearbook. Moreover, the 500-page book is set out like a scientific treatise; it includes almost 3,000 notes, some 2,000 references to scientific papers, and was published by an academic publisher. "Most importantly," explains Breydensholt, a retired high-court judge, "it has been discussed widely in the scientific community."

Support for the Danish committees came from Hans-Heinrich Trute, the ombudsman for Germany's main research funding agency, the DFG. He says that his office, which considers misconduct cases in Germany, would have authorized an investigation in such circumstances.

The Committees on Scientific Dishonesty was also criticized by Lomborg and his supporters for relying on already available critiques of the book, such as those published in Scientific American in January 2002, rather than conducting its own analysis. "We thought long and hard about whether to institute an international panel of experts to reanalyse the issues," says Breydensholt, "but decided that it was not necessary."

Lomborg strongly contests the verdict. "The committees made no judgement on the substance of the book, only the methodology," he complains. He argues that as a policy book it should not in any case have been judged by a scientific committee. "It is a popular book aimed at a broad audience," he says.

The committees' findings seem unlikely to threaten his position in Denmark. Ole Christiansen, an economist and chairman of the IEA's board of directors, says that, as the committees did not raise any new accusations against Lomborg, he would recommend that the board take no action against him. "The real debate took place a year ago," Christiansen says.

But the IEA may yet face pressure over Lomborg's position. The institute was created by a right-leaning coalition government that ousted the long-ruling Social Democrats in the November 2001 elections. Now the opposition parties say the committees' verdict confirms their criticisms of Lomborg's appointment, which they say was politically motivated. They have already called for his removal.

The government responded by saying it would consider commissioning an international evaluation of the eight or so reports that the IEA has so far produced.

On the international front, several scientists praised the committees' verdict. "I am relieved that an independent body has clarified to non-scientists that the book is an opinion piece, not a rigorous scientific work," says David Tilman, a biodiversity expert at the University of Minnesota. 